\title{
The New Forest*
}

$\mathrm{O}^{\mathrm{R}}$ RIGINALLY an old Crown forest, and nowadays the most extensive of these remnants of the old Royal forests, the New Forest, in Hampshire, comprises some 90,000 acres and is under the management of the Forestry Commissioners. The Forest comes under the designation of a true forest, though large areas consist of open heath-land subject to rights of grazing and so forth ; these limit planting and other forestry operations which would constitute the area a commercial proposition. Perhaps no other area of the type has received so much attention from Parliament, and numerous Acts have been passed for the administration of the law relating to it. The Acts of 1877 and 1879 may be said practically to have settled the Government policy vis-à-vis the forest, which is now regarded as a national play. ground; the coming of the motor-car having enormously extended the area from which visitors now resort to the Forest. These factors are rendering its management, even from the sole point of view of maintaining its beauty for future generations, a delicate and difficult task.

Apart from the Forestry Commission, several bodies such as the New Forest Association, the Court of Verderers, the Scapa Society, the Council for the Preservation of Rural England and the New Forestry Advisory Committee constitute what may perhaps be best expressed as vigilant committees over the maintenance of the Forest in its pristine beauty.

Some of the difficulties confronting the management are portrayed in the annual report for 1936 of the New Forest Association. The objects of the Association are given as follows: "The preservation of the general picturesque aspect of the Forest and the old woods and the protection of the rights and privileges of the Commoners and of the Public in the enjoyment of the Forest." From the professional forester's point of view, some of these objects are conflicting, so far as the public are concerned. To give one instance, the preservation of the picturesqueness of the old woods, for example, the Mark Ash inclosure of old beech, famous during the past half century amongst artists and other lovers of scenic beauty. How is this old wood to be perpetuated? The wooded parts of the forest, the beautiful in. closures of old broad-leaved trees, present analogous cases.

The New Forest Association has its own problems. One of the first mentioned would be scarcely under. stood by European Continental nations, accustomed to regard forests as economic commercial propositions. The matter in question is the spread of seedling fir trees coming up from blown seed. The spread of these young trees is said to be continuing at an alarming rate; with the obvious result that their growth in height will interfere with the beautiful views over the open forest, which it is one of the objects of the Association to maintain; whilst it is said that the presence of the trees diminishes the grazing area. The attention of the Forestry Commission has been directed to this, one of Nature's own acts. It is a curious anomaly to find man fighting against Nature in her effort to provide him with produce free of

* New Forest Association. Annual Report and Statement of Accounts. Pp. $18+6$ plates. (Brockenhurst : Capt. Cecil Sutton, Hon. Sec., The Estate Offices, 1936.) cost ; whilst elsewhere in the country the Commission is spending pounds per acre planting the very same type of tree. The cost of continually removing these young trees would, it is said, be considerable.

If one of the objects is to maintain the grazing, should not such work be undertaken by the right holders who own the grazing? The Association suggests a special grant being made by Government; but it is difficult to see how the expenditure of the tax-payers' money on such an object could be justified.

The Association has saved the Forest from pylons, but with the praiseworthy aim of making electricity more commonly available, poles and overhead cables are on the increase. The report alludes to litter dumping and the refuse left by visitors, and rightly considers that education and persuasion, of the old as well as the young, are the chief means by which litter may be gradually decreased.

The New Forest ponies present a problem. Within the Forest boundaries they are on their own ground. But of late years they have taken to straying outside the boundaries. In the days before the motor-cars on the roads had reached their present numbers, there were gates on the roads leading into the Forest. The value of these latter, nowadays always left open, has disappeared. The 'grid', so commonly seen at the entrance to drives of private houses, was suggested, but the County Surveyor expressed his opinion that his Council would not be prepared to make the grids. So this problem remains unsettled. Oil prospecting in the Forest has raised a scare, but nothing definite has yet transpired, save the fact that the Association would raise the strongest objection to the desecration of the Forest by such operations.

All the inclosures in the Forest have gates, a field gate and a small hunting gate alongside. These are all left unlocked. The Association quite correctly urges on the public always to close the gates on passing through; or the courtesy of the Forestry Commission in leaving the gates open may be withdrawn.

Probably the most important part of the report lies in the remarks on the condition of the Forest, and these remarks will receive support from many who, though non-resident, are well acquainted with the Forest. As the report puts it: "The Council have for many years past viewed, with great concern and alarm, the great deterioration in the condition of the open and enclosed spaces of the Forest to which the public have access. They interpret the New Forest Act 1877 as laying down that the amenity of the Forest is the object of management, and that any consideration of profit should take a second place." It may be mentioned that in many parts of the Continent of Europe it is regarded as quite feasible to secure both objects by a correct management without a loss of amenity. But the present condition of parts of the Forest is reducing amenity and its use by the public and is equally uneconomic. The most glaring item in this want of management is the neglect of draining over areas of varying size throughout the region-a neglect which cannot be laid to the door of the Forestry Commission; for it is the aftermath of the want of efficient management in these matters of a century or more. 